DOI: 10.17707/AgricultForest.63.3.06

\begin{abstract}
Aleksandra DESPOTOVIĆ, Miljan JOKSIMOVIĆ, Kristina SVRŽNJAK and Miomir JOVANOVIĆ ${ }^{1}$
\end{abstract}

\title{
RURAL AREAS SUSTAINABILITY: \\ AGRICULTURAL DIVERSIFICATION AND OPPORTUNITIES FOR AGRI-TOURISM DEVELOPMENT
}

\begin{abstract}
SUMMARY
The paper analyses socio-demographic and production potentials and opportunities for agri-tourism development. The research was carried out on holdings in the northern regions of Montenegro and Croatia. The focus is placed on family holdings with agriculture being the primary activity. The results show presence of certain production and socio-demographic preconditions for development of agri-tourism as a supplementary activity on holdings. In future, agri-tourism could encourage development of rural communities surveyed. Respondents identify state institutions as the key players in agri-tourism development. Agricultural holdings are not sufficiently networked, either vertically or horizontally, with the state and local institutions. Future agri-tourism development in Montenegro and Croatia should be based on sustainable development principles.
\end{abstract} community

Keywords: agri-tourism, agriculture, sustainable development, rural

\section{INTRODUCTION}

Over the past few decades, rural areas have been affected by exploitation of natural resources, depopulation and fall in agricultural production [1]. Agriculture is particularly important for mountainous areas [2]. It is not only about food production, but it also contributes to environmental protection and valorisation of human and natural resources $[3,4]$. The specific character of the agricultural production stipulates the main bottleneck: possibilities to replace labour and land with capital in rural areas are limited [5]. Agri-tourism can initiate the process of agriculture diversification and influence revitalisation of rural areas [6].

The agricultural activity has always contributed to the creation of rural landscapes which we can enjoy today, to human permanence in areas which are otherwise exposed to degradation, to determine and social values, to create a body of knowledge that are typical of specific areas, to valorise the human, economic and environmental resources of the various rural communities, to

\footnotetext{
${ }^{1}$ Aleksandra Despotović, Miljan Joksimović, Miomir Jovanović (corresponding author: miomirj@tcom.me), University of Montenegro, Biotechnical Faculty, Department for Agro-Economic Research, Podgorica, MONTENEGRO; Kristina Svržnjak, College of Agriculture, Križevci, CROATIA.

Notes: The authors declare that they have no conflicts of interest. Authorship Form signed online.
} 
qualify and promote the image of many territories, increasing their attractive capacities and contributing to their development [7].

Multifunctionality of agriculture is important for balanced regional development [8]. According to Binder and Wit [9] the multifuncionality of agriculture is a way to indicate evolutionary paths of differentiation and integration of income for farmers, especially in marginal areas where the business competitiveness is particularly difficult to achieve in function of territorial structural weaknesses. In many developing countries agriculture is vital for sustainable rural development and recognized as a main means for reducing poverty and ensuring economic growth. In this sense, reducing poverty in rural areas depends significantly on sustainable agricultural development [10]. In developed economies, agriculture is increasingly considered in a systemic approach, able to produce food commodities and meet the new needs of the consumer, providing both public goods (biodiversity, agricultural landscape) and services (tourism, energy, educational services) and foods with specific attributes (typical products) [11,12]. In the last years, to promote rural development policies the public operator has established a multifunctional vision of agricultural activity, attributing its multiple functions and responding to the new society needs [13]. According to Ficher [14] in this way there are farms which, at the same time, contribute to food production, preservation of natural resources, employment and sustainable development of the rural territory.

Intensive development of urban areas contributes to increased demand for holidays in rural areas $[15,16]$. In developed countries, agri-tourims has a long tradition [17]. Tourism, especially in rural areas, is one of the developing sectors in the European Union (EU) economy. Throughout the world, the countryside has become a common tourism destination $[17,18]$. Farm owners in rural areas perform a variety of activities by, for instance, combing agricultural production and tourism $[19,20]$.

There are different definitions of agri-tourism in literature. Agri-tourism is an activity organised by agricultural producers [21]. Working farms with growing crops and livestock are one of the most important attractions during a stay on an agri-tourism farm [22]. In the context of sustainable rural development, agriculture as a tourism and recreation source can be considered an opportunity for rural areas. Any tourism or recreation enterprise on a working farm or form of rural tourism whereby paying guests can participate in farming life either as staying guests or day visitors on working farms can be seen as a new income source for agricultural societies $[15,16]$. Agri-tourism is a valued option protecting the rural environment, sustaining small sized enterprises and providing income and job opportunities [23]. With the post-industrial revolution, urbanisation and increased leisure time, tourism and recreation activities in rural areas also increased. Agri-tourism, which is defined as any tourism or recreation enterprise on a working farm, or a form of rural tourism whereby paying guests can participate in farming life either as staying guests or day visitors on working farms, can be seen as a new income source for agricultural societies [15,16]. Sale of own products and enlargement of farms is an important motive of agricultural 
producers for engaging in agri-tourism $[24,25,26]$. In short, agri-tourism is one of the forms of rural tourism that allows tourists to spend leisure time by staying on a working farm [27].

The advantages of agri-tourism development are reflected in preservation of agricultural areas in rural regions as well as on-farm selling of own products [28]. Agri-tourism is becoming an important factor for survival of small agricultural holdings that are not able to compete under conditions imposed by market globalisation [29]. Agri-tourism is an important instrument for improving the social status of women and creating conditions for their inclusion in agritourism activities [23].

The research presented in this paper was carried out on family agricultural holdings in the northern regions of Montenegro and Croatia. The region disposes of significant natural resources. Agricultural soil is among the most important ones. The Koprivnica-Križevci County covers an area of $1,746 \mathrm{~km} 2$, of which arable land accounts for 59\% [30]. The situation is similar in the northern region of Montenegro [31]. Agriculture is the basis of social, economic and local development. Income from agriculture is unstable and agri-tourism provides an opportunity for supplementing the income in the holdings surveyed [32].

The theoretical approach for this paper takes agri-tourism as a supplementary activity enabling sale of own products, board and lodging as well as other active holidays services on a holding $[1,33]$. These activities enable better utilisation of production and human resources on a holding [34]

The objective of the research presented in this paper is analysis of sociodemographic and production potentials on agricultural holdings and opportunities for agri-tourism development.

\section{Study Area}

\section{MATERIALS AND METHODS}

Although Montenegro and Croatia had a different historical development, decades long joint state legal framework contributed to suppression of numerous differences in the way of living of rural communities. The reason for addressing this topic is based on the fact that Montenegro and Croatia recognized tourism as the basis of economic development. In that context, agri-tourism is particularly important.

The northern region covers more than $50 \%$ of the entire territory of Montenegro, and accounts for one-third of the entire population. Towns of Bijelo Polje, Pljevlja and Kolašin, where the survey was conducted, account for $23 \%$ of the entire area of Montenegro (Fig.1). The Koprivnica-Križevci County is situated in the north of Croatia and covers $3.2 \%$ of the total territory of Croatia. It includes the following towns: Križevci, Koprivnica and Đurđevci (Fig. 2). The areas surveyed have moderate continental climate with pronounced extremes of certain climatic elements. The area disposes of hydrographic potentials of the rivers Drava, Tara, Lim and Bistrica.

Agricultural production is the core activity of family holdings in the northern region of Montenegro and Croatia. An average agricultural holding in 
Montenegro disposes of 4.6 ha of agricultural land, and in Croatia of 5.6 ha [30, 31, 35]. The main characteristic of holdings is fragmentation of land parcels, traditional way of living, hospitality and a diverse offer of home-made specialties. Demographic situation is unfavourable as a result of pronounced migratory trends towards southern and central regions.

The Križevci - Koprivnica County

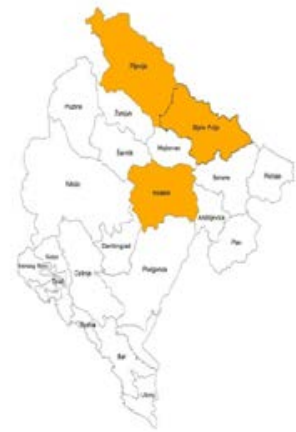

Figure 1.

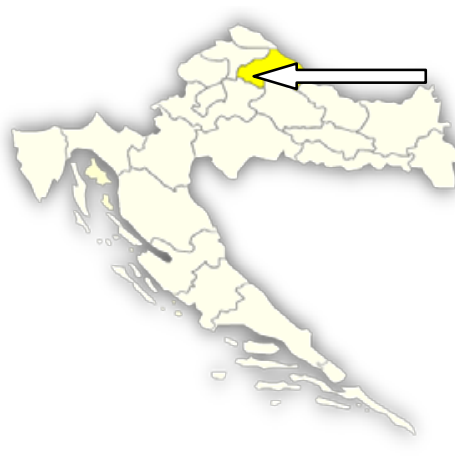

Figure 2.

Tables 1 and 2 below provide an overview of socio-demographic factors as well as number of family holdings by municipalities in which surveys presented in this paper were carried out.

Table 1. Socio-demographic factors - northern region of Montenegro and the Koprivnica-Križevci County

\begin{tabular}{|c|c|c|c|}
\hline $\begin{array}{c}\text { Geographic } \\
\text { distribution }\end{array}$ & Area, km2 & Population & $\begin{array}{c}\text { Population } \\
\text { density per } \mathbf{~ k m}^{2}\end{array}$ \\
\hline Montenegro & 13,812 & 620,029 & 45 \\
\hline Pljevlja & 1,346 & 36,918 & 23 \\
\hline Bijelo Polje & 924 & 46,051 & 50 \\
\hline Kolašin & 897 & 8,380 & 9 \\
\hline Croatia & 56,542 & $4,284,889$ & 76 \\
\hline Koprivnica & 90.94 & 30,854 & 340 \\
\hline Križevci & 263.70 & 21,122 & 80 \\
\hline Đurđevac & 157.19 & 8,264 & 53 \\
\hline *Source [64, 65]
\end{tabular}

Natural, social and transport factors are important for agri-tourism development [34]. The northern regions of Montenegro and Croatia dispose of significant natural resources (mountains, lakes, caves, national parks, flora and fauna, rivers abundant with fishery resources). The national park Biogradska Gora in the vicinity of Kolašin is one of three last old-growth forests in Europe. The Biogradsko Lake, which belongs to the group of glacial lakes, is in the centre of the National Park. The Mountain Bjelasica is rich in flora and fauna (26 plant communities with around 2000 species and subspecies of higher plants) as well as mountain lakes. The County has Šoderica and Čambina lakes, Fortress Kalnik, 
Đurđevečki Peski etc. Existing resources provide an opportunity for various tourist attractions, such as mountaineering, hunting, fishing, etc. [36].

Table 2. Number of family agricultural holdings in the area surveyed

\begin{tabular}{|c|c|c|}
\hline Geographic distribution & $\begin{array}{c}\text { Number of family } \\
\text { holdings }\end{array}$ & $\begin{array}{c}\text { \% share in total } \\
\text { number of holdings }\end{array}$ \\
\hline Montenegro & 48,824 & 100.00 \\
\hline Pljevlja & 4,001 & 8.19 \\
\hline Bijelo Polje & 6,404 & 13.11 \\
\hline Kolašin & 1,574 & 3.22 \\
\hline Croatia & 230,000 & 100.00 \\
\hline Koprivnica & 10,238 & 4.45 \\
\hline Križevci & 7,001 & 3.04 \\
\hline Durđevac & 2,857 & 1.25 \\
\hline
\end{tabular}

*Source $[65,16]$

Natural, social and transport factors are important for agri-tourism development [34]. The northern regions of Montenegro and Croatia dispose of significant natural resources (mountains, lakes, caves, national parks, flora and fauna, rivers abundant with fishery resources). The national park Biogradska Gora in the vicinity of Kolašin is one of three last old-growth forests in Europe. The Biogradsko Lake, which belongs to the group of glacial lakes, is in the centre of the National Park. The Mountain Bjelasica is rich in flora and fauna (26 plant communities with around 2000 species and subspecies of higher plants) as well as mountain lakes. The County has Šoderica and Čambina lakes, Fortress Kalnik, Đurđevečki Peski etc. Existing resources provide an opportunity for various tourist attractions, such as mountaineering, hunting, fishing, etc. [36].

In the region surveyed, cultural and historical heritage and thematic events throughout the year are important social factors. In Montenegrin municipalities, there are monuments dating back to $16^{\text {th }}$ century: the Monastery of the Holy Trinity and Husein Pasa's Mosque, as well as the Monastery Morača, built in 1252. The County has sacred structures (Church of the Assumption of Blessed Virgin Mary, chapel St. Mark of Križevci) and a strongly developed artistic tradition. Cultural and historical monuments are situated in urban and suburban zones. Events of importance for the region are: the Days of Pljevlja Cheese, the Tara River Rafting, Picokijada in Đurđevac, Renaissance Festival in Koprivnica, etc. Well-known agricultural products are: pljevaljski cheese, lisnati cheese and prgica cheese [1].

From the viewpoint of transport factors, the family holdings surveyed have infrastructure connection with zones with cultural and historical monuments. However, current road infrastructure requires major investments for the purpose of modernization.

\section{Material}

The first part of the paper is based on available literature sources. The results of the survey conducted on 120 agricultural holdings (60 agricultural 
holdings in the northern region of Montenegro and the Koprivnica-Križevci County, each) are presented in the second part of the paper. The survey questionnaire includes questions on socio-demographic characteristics, while the second part concerns production characteristics and potentials of the holdings. The survey was carried out in the course of 2015 by trained poll takers.

\section{Method}

The survey was carried out in the form of interviews. The survey covered age groups of 18 years and over. The respondents were selected by random sampling. According to methodology, persons surveyed can be holders of family holdings or their members. Similarities and differences on agricultural holdings in Montenegro and Croatia were analysed by the method of comparison. Data was processed using SPSS software, and the methods used included descriptive statistics, outlier detection, five maximum and five minimum variables, frequency, correlation and cross-tabulation.

\section{Hypotheses}

The following hypotheses were formulated in this paper: $\mathrm{H}_{1}$ : Agriculture is the core activity in the holdings surveyed; $\mathrm{H}_{2}$ : Holdings dispose of sociodemographic and production potentials for development of agri-tourism as supplementary activity; $\mathrm{H}_{3}$ : The main motives of respondents for engaging in agri-tourism include: sale of own products on holdings and income increase.

\section{RESULTS AND DISCUSSION \\ Socio-demographic data on holdings}

Respondents were predominantly male, accounting for $78.4 \%$ of all respondents (Tab.3). Most of the respondents fell within the age group of up to 30 , with secondary education. Most of respondents (63.6\%) stated that their main occupation is agricultural producer, with 16.4 ha on average, with highest share of producers with 5.5 ha. Respondents who are not agricultural producers dispose of largest land areas. Smaller villages with population of up to 500 is the residence of $48.8 \%$ of respondents who dispose of 136.7 ha, on average, within which respondents with 66.7 ha have the highest frequency. The key preconditions for development of agri-tourism in family holdings are: agriculture as the core activity, available land resources and location in rural areas [37,17].

Land is the most important means of production on holdings [38]. According to the production type (Tab.4), purely agricultural holdings prevail. Agriculture is the core activity and the driving force of agri-tourism development [38].

From the viewpoint of agri-tourism development in the holdings surveyed, agricultural producers have the opportunity to rent the land and thus strengthen further their production capacity. On the other hand, a part of the land resources can be used for tourism purposes (for construction of smaller tourist accommodation facilities, sports grounds, etc. [38]. Most of respondents stated that currently, they do not dispose of appropriate tourist accommodation facilities. 
Table 3. Socio-demographic data of holdings surveyed in Montenegro and Croatia

\begin{tabular}{|c|c|c|c|c|c|c|}
\hline \multirow{2}{*}{\multicolumn{2}{|c|}{$\begin{array}{l}\text { Socio-demographic } \\
\text { data on holdings }\end{array}$}} & Montenegro & Croatia & Structure & Average & $\begin{array}{c}\text { Pondered value } \\
\text { according to } \\
\text { number of ha }\end{array}$ \\
\hline & & $\%$ & $\%$ & $\%$ & ha & ha \\
\hline \multirow{2}{*}{ Sex } & Male & 90.0 & 68.0 & 78.4 & 37.7 & 29.6 \\
\hline & Female & 10.0 & 32.0 & 21.6 & 282.2 & 61.0 \\
\hline \multirow{4}{*}{ Age } & Age $15-30$ & 3.3 & 94.0 & 50.4 & 167.6 & 84.5 \\
\hline & Age 31-50 & 51.6 & 6.15 & 28.0 & 11.07 & 3.3 \\
\hline & Age 51-65 & 33.3 & 0 & 16.0 & 13.8 & 2.2 \\
\hline & Above 65 & 11.8 & 0 & 5.6 & 12.7 & 0.7 \\
\hline \multicolumn{7}{|c|}{$\begin{array}{c}\text { Educational structure } \\
\text { of the population }\end{array}$} \\
\hline \multicolumn{2}{|c|}{$\begin{array}{l}\text { Elementary - } \\
\text { incomplete }\end{array}$} & 3.30 & - & 1.6 & 14.5 & 0,2 \\
\hline \multicolumn{2}{|c|}{$\begin{array}{c}\text { Elementary education } \\
\text { completed }\end{array}$} & 18.30 & 3.30 & 8.8 & 13.5 & 1.2 \\
\hline \multicolumn{2}{|c|}{$\begin{array}{c}\text { Secondary education } \\
\text { completed }\end{array}$} & 63.30 & 85.30 & 82.4 & 107.1 & 88.3 \\
\hline \multicolumn{2}{|c|}{$\begin{array}{c}\text { College, University } \\
\text { degree }\end{array}$} & 15.0 & 11.40 & 7.2 & 12.0 & 0.9 \\
\hline \multicolumn{2}{|c|}{$\begin{array}{c}\text { Master of Science, } \\
\text { Doctor of Philosophy }\end{array}$} & - & - & - & - & \\
\hline \multicolumn{7}{|c|}{ Occupation } \\
\hline \multicolumn{2}{|c|}{ Agricultural producer } & 63.30 & 58.90 & 63.6 & 16.4 & 5.5 \\
\hline \multicolumn{2}{|c|}{ Pensioner } & 7.60 & 10.78 & 3.2 & 4.2 & 0.1 \\
\hline \multicolumn{2}{|c|}{ Other } & 29.10 & 30.32 & 33.2 & 130.9 & 82.7 \\
\hline \multicolumn{7}{|c|}{ Residential status } \\
\hline \multicolumn{2}{|c|}{$\begin{array}{c}\text { Smaller village } \\
\text { (population up to 500) }\end{array}$} & 55.0 & 43.0 & 48.8 & 136.7 & 66.7 \\
\hline \multicolumn{2}{|c|}{$\begin{array}{c}\text { Medium-sized village } \\
\text { (population 500-1,000) }\end{array}$} & 3.30 & 26.5 & 12 & 49.8 & 6.0 \\
\hline \multicolumn{2}{|c|}{$\begin{array}{c}\text { Larger village } \\
\text { (population 2,000- } \\
5,000)\end{array}$} & 36.7 & 27.5 & 23.2 & 19.1 & 4.4 \\
\hline \multicolumn{2}{|c|}{$\begin{array}{c}\text { Larger town } \\
\text { (population 5,000- } \\
10,000 \text { ) }\end{array}$} & 5.0 & 3.0 & 16 & 83.55 & 13.4 \\
\hline \multicolumn{2}{|c|}{$\begin{array}{c}\text { Large town (population } \\
10,000 \text { ) }\end{array}$} & - & - & - & - & \\
\hline
\end{tabular}

In the ownership structure, parents have the highest share (60\%), while respondents account for $30 \%$. Under the frequency distribution, parents dispose of 15.9 ha, and respondents with 4.3 ha (Tab.4). The results show the link between respondents and the work and life on a family holding. Taking into account the share of respondents of up to 30 years of age in the ownership structure, they can respond to the needs of provision of tourism-hospitality services [39]. 
Most of holdings (24.6\%) have more than five members. Human resources are an important factor on holdings, as they contribute to the generation of the new value $[40,41]$. In the sample observed, almost all family members participate in agricultural activities (80\%).

Table 4. Data on production status of holdings surveyed in Montenegro and Croatia

\begin{tabular}{|c|c|c|c|c|c|}
\hline \multirow[t]{2}{*}{$\begin{array}{l}\text { Ownership } \\
\text { structure of } \\
\text { holdings }\end{array}$} & Montenegro & Croatia & Structure & Average & $\begin{array}{c}\text { Pondered } \\
\text { value } \\
\text { according to } \\
\text { number of ha } \\
\end{array}$ \\
\hline & $\%$ & $\%$ & $\%$ & ha & ha \\
\hline My parents & 34.4 & 91.3 & 60.4 & 26.3 & 15.9 \\
\hline My grandparents & 3.3 & 3.2 & 4.0 & 23.5 & 0.9 \\
\hline Me, personally & 55.7 & 2.2 & 30.6 & 14.19 & 4.3 \\
\hline Others & 6.6 & 3.3 & 5.0 & 137,4 & 6.9 \\
\hline \multicolumn{6}{|l|}{$\begin{array}{l}\text { Number of members } \\
\text { on the holding }\end{array}$} \\
\hline 2 members & 16.4 & 15.3 & 15.2 & 341.1 & 51.8 \\
\hline 3 members & 21.3 & 16.22 & 23.2 & 18.5 & 4.3 \\
\hline 4 members & 11.5 & 43.0 & 23.2 & 31.6 & 7.3 \\
\hline 5 members & 18.0 & 11.23 & 13,8 & 24.3 & 3.4 \\
\hline$>5$ members & 32.8 & 15.25 & 24.6 & 99.7 & 24.5 \\
\hline \multicolumn{6}{|l|}{$\begin{array}{c}\text { Participation in work } \\
\text { on the holding }\end{array}$} \\
\hline Family members only & 90.0 & 55.0 & 80.0 & 81.2 & 65.0 \\
\hline $\begin{array}{l}\text { Family members and } \\
\text { workers }\end{array}$ & 8.60 & 11.66 & 14.6 & 42 & 6.1 \\
\hline $\begin{array}{c}\text { Seasonal / temporary } \\
\text { workers }\end{array}$ & 1.40 & 33.34 & 5.4 & 767 & 41.4 \\
\hline \multicolumn{6}{|l|}{ Production type } \\
\hline $\begin{array}{c}\text { Purely agricultural } \\
\text { holding }\end{array}$ & 80.0 & 52.3 & 65.6 & 26.6 & 17.4 \\
\hline Mixed holding & 16.7 & 46.87 & 32 & 77.8 & 24.9 \\
\hline $\begin{array}{c}\text { Non-agricultural } \\
\text { holding }\end{array}$ & 3.3 & 0.83 & 2.4 & 1501 & 36.0 \\
\hline
\end{tabular}

One of general requirements that a holding should fulfil in order to engage in agri-tourism is keeping livestock and other domestic animals [39]. Attractiveness of a holding rises significantly if tourists are able to join the agricultural activities, and children can interact with domestic animals [34]. In the holdings surveyed, livestock and field crop production prevails (45\%). Presence of plant and livestock production enables tourists to participate actively in routine daily work on a holding.

More than $50 \%$ of respondents are engaged in production of autochthonous products of which $55.8 \%$ market their products on their own holding and thus generate income. Meat and dairy products prevail in the product 
structure (41.4\%). The share of processed fruit, vegetable and other products is significant as well. Taking into account the existing production on holdings, gastronomic offer is an important element that can significantly increase the income.

The preconditions analysed provide an opportunity for integration of agritourism as a supplementary activity in holdings surveyed. Socio-economic and natural factors are an important generator of agri-tourism turnover.[42]

The respondents in the survey are market oriented. The respondents stated on-farm sale of own products and increase of income as the most important motives for engaging in agri-tourism [24,25,26,32,38,43].

Table 5. Motives for launching agri-tourism activity in holdings surveyed

\begin{tabular}{|c|c|c|c|c|c|}
\hline Motives & Montenegro & Croatia & Structure & Average & $\begin{array}{c}\text { Pondered } \\
\text { value } \\
\text { according to } \\
\text { number of ha }\end{array}$ \\
\hline $\begin{array}{c}\text { Sale of own } \\
\text { products, easier } \\
\text { marketing }\end{array}$ & 85.5 & 54.5 & 70.0 & 124.5 & 87.15 \\
\hline $\begin{array}{c}\text { Income } \\
\text { increase }\end{array}$ & 5.5 & 20.0 & 12.75 & 44.75 & 5.6 \\
\hline $\begin{array}{c}\text { Reduction of } \\
\text { agricultural } \\
\text { production } \\
\text { risks }\end{array}$ & 1.8 & 7.3 & 4.55 & 86.5 & 3,9 \\
\hline $\begin{array}{c}\text { Employment } \\
\text { for family } \\
\text { members }\end{array}$ & 1.8 & 9.1 & 5.45 & 21.83 & 1.2 \\
\hline \begin{tabular}{c} 
Other \\
\hline
\end{tabular} & 5.5 & 9,1 & 7.3 & 22.4 & 1.63 \\
\hline
\end{tabular}

Development of contemporary product distribution channels create the potential risk of complete disappearance of local produce that is produced in small quantities. Agri-tourism is an activity that provides market opportunities for products from the small production volume [38].

Engaging in agri-tourism requires interest in and knowledge of family members in numerous areas [43]. Most of respondents (80\%) are not familiar with the legislation and procedures for launching agri-tourism activities; nevertheless, 76\% expressed interest in engaging in this activity. That is why training is necessary for work in agri-tourism as well as inclusion of stakeholders in tourism who possess the know-how and experience [43]. The stakeholders in agri-tourism are representatives of government institutions, local communities, tourist agencies and holdings connected with agri-tourism $[44,45]$. The support of local communities and co-operation among business operators are important preconditions for integration of agri-tourism as a supplementary activity on 
holdings [46]. Public and private sectors play different roles. The public sector is in charge of enforcement of laws and implementation of standards, while the private sector plays an important role in development of facilities for implementation of agri-tourism activities [47]. An important feature of holdings engaged in agri-tourism is that their operations depend on their own resources and that members of the holding are responsible for the services provided to tourists [48].

Agri-tourism requires a dynamic harmony in operations of all stakeholders participating in the business. Organization and interaction are important for holdings, agri-tourism associations and institutions. This implies vertical, horizontal and territorial integration of the stakeholders and their joint activities [38].

Management of agri-tourism potential in the region surveyed falls under the authority of the Ministry of Agriculture and local secretariats for economy and agriculture. The role of the Ministry of Agriculture is to create an environment and provide incentives for agri-tourism development. The incentives take the form of measures of support to rural development. In Croatia, those support measures include grant support to launching agri-tourism activities as well as financing of existing tourism-related activities on holdings. In addition to subsidies, the local administrations assist producers in organization of events and include them in cross-border projects, shares information on the programmes of the Ministry of Agriculture, etc. The flow of information is "top-down". Tourism organizations work on promotion of local communities, but far more extensive promotion of agri-tourism potential is needed. In the view of respondents (60\%), self-initiative of holding members can influence significantly the demand in agri-tourism, while $36.4 \%$ of respondents attributes it to the state policy. Local community as a factor in agri-tourism development is identified by a small number of respondents (3.6\%). Research activities carried out thus far indicate the need for better involvement of local community members in order to ensure development of a tourist destination in accordance with the local character and values [49].

A number of non-governmental organizations invest significant efforts in order to connect agricultural holdings and interested tourists. Local Action Group (LAG) is important for establishing of local partnership, while LAG is important for the LEADER program. LEADER - Links between actions for the development of the rural economy, is a European Union initiative to support rural development in rural communities through public-private partnership (LAGs). The main LEADER characteristic is that the emphasis is placed on local population and its ability to identify what suits best their tradition, skills, culture, environment [50]. The basic LEADER principle is "bottom-up" approach. It is based on LAGs, networking, local financing, etc.

There are three LAGs on the territory of the Koprivnica-Križevci County: LAG Prigorje, LAG Podravina and LAG Prizak. LAG Prigorje is currently inactive. In Montenegro, LAGs are at the initial stage. The Rural Development 
Network in Montenegro plays an important role in mobilizing civil society in rural areas and promotion of the rural development concept. The network currently has 18 members, interested in promotion of cultural and historical heritage, education, etc. The network aspires to extend its membership with a view to promoting the natural potential for agri-tourism in the region observed. Thus far, networking of producers and cooperatives through setting up of local associations on the territory of Montenegro has not fully met the expectations.

There have been initiatives for establishing of agri-tourism clusters in the surveyed regions of Montenegro and Croatia. Concrete steps in that regard have not been taken yet.

On the territory of Croatia, agri-tourism development is monitored by the Croatian Chamber of Economy, and the Association of Tourism Agricultural Holdings was established as well. A specific body in charge of agri-tourism development has not been established in Montenegro yet. Its establishing falls under the authority of the Ministry of Agriculture, more precisely, of the Directorate for Rural Development.

Dissemination of importance and role of agri-tourism requires inclusion of educational institutions and experts in this field. It is important to work on development of specialized know-how in information and communication technologies, management, marketing, trade, etc. [1]. The ultimate objective of training (courses, discussions, workshops, etc.) is that trainees understand the contribution that agri-tourism can make to their region. Education and training is needed for direct service providers as well as for employees in the national and local administration.

As major obstacle to agri-tourism development, the respondents highlight the lack of funds (57\%). Failure factors in development of agri-tourism activity are mainly referred to the national institutions. Rural population in Montenegro and Croatia almost entirely relies on agriculture as the basis of the rural economy. That is why their expectation that agri-tourism development should be the objective of the Ministry of Agriculture is logical. Thus far, the incentives offered by the state have not been sufficiently encouraging. In Montenegro and in Croatia, agri-tourism is still not developed endogenously, but is for the most part relying on "external" investments, through applications for European funds, such as IPARD and similar.

Respondents (85\%) note that agri-tourism entails certain risks. The risks faced by holdings can be financial, legal, market related, etc. Studies show that in some communities, local population is more interested in environment than in economic benefits that agri-tourism brings [38,43]. The views range from concerns with regard to environmental consequences on one side to the pronounced optimism regarding economic development on the other. However, regardless of the risks, (84.75\%) of respondents believe that demand in agritourism will grow in the future. Entrepreneurs, private land/house owners and local community will express more interest in development of agri-tourism. They are searching for new developmental and employment opportunities for the local 
population. It can be in conflict with interests of owners of holiday homes, ecologists and national environmental protection agencies who are concerned that agri-tourism could cause harm to the environment [51].

That agri-tourism contributes positively to socio-economic development of rural communities is the view shared by $56 \%$ of respondents. As main contributions, they indicate marketing of own products and income increase, increase in volume of agricultural production, preservation of tradition, improvement of the conditions and quality of life. Taking into account the natural and cultural diversity of the region observed, agri-tourism can become a driving force of a range of activities on family holdings (organic food production, revitalization of old artisan skills, etc.).

The survey conducted confirmed the hypotheses presented in the paper. In holdings observed, agriculture is the main activity, which confirms the first hypothesis. The potential that holdings dispose of confirm the hypothesis that preconditions for development of agri-tourism as a supplementary activity exist. Respondents state easier marketing and sale of own products as the main motivation for engaging in agri-tourism in order to increase income. Thus, the last hypothesis is confirmed.

\section{CONCLUSION}

Northern region of Montenegro and Croatia are traditional agricultural areas. The paper analyses the production and socio-demographic potentials and opportunities for development of agri-tourism on holdings. The survey was carried out in the northern regions of Montenegro and Croatia. The results of the survey show that the holdings surveyed dispose of land and human resources, but their accommodation capacity is insufficient. One of drawbacks is lack of quality infrastructure and connection with the urban areas.

Majority of holdings are situated in smaller villages with population of up to 500. Agriculture is the core activity, where livestock and field crop production prevail. Holdings are able to sell their own products directly on farms, as well as to offer active participation in routine daily farm activities. The respondents state on-farm sale of products and income increase as the main motive for engaging in agri-tourism. The holdings are in vicinity of towns with rich cultural heritage.

The respondents lack knowledge on agri-tourism and are not familiar with legislation and procedures. They state lack of financial means as an obstacle to engaging in agri-tourism. They see national institutions as the main "culprits" for insufficient development of agri-tourism, but they also see them as the key players in future development. Respondents believe that local communities and family holdings are far less responsible for agri-tourism development.

In order to put in place a more complex agri-tourism product, cooperation among all stakeholders in a local community is necessary. There is a need for both vertical and horizontal networking of stakeholders in agri-tourism development, both at the national and the local levels. 
Development of agri-tourism as a supplementary activity on holdings requires stronger institutional support. It is reflected in easier access to finances and loans, provision of technical and advisory services to producers, support to project development and management. All agri-tourism stakeholders should have in mind that no sector is able to cope with major social, economic and environmental challenges on its own. Each partner contributes with its qualities and competences and plays a specific role in designing and implementation of projects and activities.

Agri-tourism development in destinations surveyed provides opportunities for establishing of contacts among people, exchange of experiences, contributes to preservation of the local heritage and multicultural character. The benefits of the local community from agri-tourism development include better social infrastructure (schools, libraries, health care institutions, etc.). Furthermore, agritourism initiates better valorisation of natural resources of rural communities. In order to increase the attractiveness of the region surveyed, it is necessary to valorise the available natural potentials through various activities (fishing, swimming, boating, bird watching, collection of medicinal herbs, visits to protected natural areas, etc.).

On the other hand, the tourist offer that a destination should promote requires bringing together a long chain of stakeholders. Agri-tourism development must not be random and unplanned, but planned, controlled and continued.

In future, establishing of agri-tourism clusters is necessary in order to meet the joint interests and promote agri-tourism activities. Joint efforts should contribute to improvement of the quality of services in holdings. Association in clusters results in linking of agriculture with artisanship and other activities; specialized production; raising awareness on importance of agri-tourism for rural communities; offering of new services on farms; better infrastructure. Thus, holdings become more attractive.

Particular attention needs to be paid to setting up of a national database on agri-tourism in Montenegro. Such data are needed because statistical data are of immense importance for monitoring of economic and social situation in a country. Monitoring of the number of visitors, estimate of tourist consumption, tourist polls (consumption, motivation, satisfaction) and key players in tourist offer are recommended. Availability of statistical data on agri-tourism is essential for rural development policy making.

The results obtained in this survey are important for decision-makers and agricultural policy makers. They provide information on existing preconditions (production, socio-demographic) and opportunities for agri-tourism development. Results of this paper can be used in the process of planning and implementation of rural development measures. This survey is the first of its kind in Montenegro. Its importance stems from the fact that it was carried out in two neighbouring countries - one is a Member State of the EU, the other is on its path towards the EU. 


\section{ACKNOWLEDGEMENTS}

This work result of a bilateral project with the Republic of Croatia.

\section{REFERENCES}

1.Kantar, S. Razvoj održivog ruralnog turizma: potencijal Koprivničko-križevačke županije. Doktorska disertacija, 2016, Zagreb, pp. 1-279

2.Ribeiro, M.; and Marques, C. Rural Tourism and the Development of Less Favoured Areas - between Rhetoric and Practice. Int.J. Tourism Res. 2002, 4, 211-220 .

3.Lee, K. A. and FrzipoorSaen R. Measuring corporate sustainability management: A data envelopment analysis approach. Int. J.Product Econom. 2012, 140, 219-226 .

4.Wiengarten, F.; and Pagell, M.; The importance of quality management for the success of enviromental management initiatives. Int. J.Product Econom. 2012, 140, 407415.

5.Erokhin, V.; Heijman, W.; Ivolga, A. Sustainable rural development in Russia throught diversification: The case of Stavropol Region. Visegr. Bioecon. Sustain. Dev. 2014, I, 20-25.

6.Sidali, K.I.; Kastenholz, E.; Bianchi,R. Food tourism, niche markets and products in rural tourism: Combining the intimacy model and the experience economy as a rural development strategy. J. Sustain. Tour. 2015, 23, 1179-1197.

7.Lanfranchi, M. and Giannetto, C. Sustainable development in rural areas: The new model of social farming. Quality - Access Success. 2014, 15, p. 219-223.

8.Sgroi, F.; Trapani.A.M., Testa, R. and Tudisca, S. The rural tourism as development opportunity or farms. The case of direct sales in Sicily. American Journal of Agriculture and Biological Sciences. 2014, 9 (3) , 407-419.

9.Binder, M. and Witt, U. A Critical note on the role of the capability approach for sustainability economics. J. Socio- Econom. 2012, 41, 721 -725.

10.Anonymous: Promoting Sustainable Rural Development Through Agriculture. Canadian International Agency (CIDA). Minister of public Works and Goverment Services, 2003, $\mathrm{N}_{0}$ : CD4-8/2003, Canada.

11.Ageron, B.; Gunasekaran, A.; Spalanzani, A. Sustainable supply management: An empirical study. Int. J.Product.Econom. 2012, 140, 168-182.

12.Ginaldy, F.; Danuso, F., Rosa, Rocca, A. and Bashanova, O. Agro-energy supple chain planning: A procedure to evaluate economic, energy and enviromental sustainability. Italian J. Agronomy. 2012. 7, 221-228.

13.Gray, J. The Common agricultural policy and the re-ivention of the rural in the European community. Sociol. Ruralis. 2000, 40, 30-52.

14.Fichera,C.R. Mulzifunzionlita e Svilluppo Sostenibile Del Territorio RuraleInnovazione Technologica e Valorizzazione Delle Tipicita, IN: Aree Marginali. 1 st Edn, Iriti Editore, Reggio Calabria, 2007 ISBBN -10: p. 68-88.

15.Dernol, L.A. Farm tourism in Europe. Tourism Managment. 1983, 4(3), 155-156.

16.Busby, G.; and Rendle, S. The transition from tourism on farms to farma tourism. Tourism Managment. 2000, 21, 635- 642.

17.Hall, D.; Mitchell, M., and Roberts, L. Tourism and the ciuntryside: dynamic relationships, in Hall, D.; Roberts, L. and Mitchell, M. (eds), New Directions in Rural Tourism, 2003, pp. 3-16.

18.Ainley, S.; and Smale, B.A. Profile of Canadian agritourists and the benefits they seek. Journal of Rural and Community Development. 2010, Vol 5, $\mathrm{N}_{0}$ 1, 58-75. 
19.Fennel,D.A., and Weaver, D.B. Vacation farms and ecotourism in Sascatchewan, Canada. Journal of Rural studies. 1997, Vol 13, $\mathrm{N}_{0}$ 4, 467 -475.

20.Brandth, B.; and Huagen, M.S. Farm diversification into-tourism-implications for social identity?Journal of Rural studies. 2011, 27, $\mathrm{N}_{0} 1,35-44$.

21.Brščić, K.; Franić, R., Ružić, D. Hy agrotourism -owner’s opinion. Journal of Central Europen Agriculture. 2010, Vol.11, $\mathrm{N}_{0}$ 1, 1-42.

22.Majewski, J. Agroturystyka to tez biznes, Fundacja, Wspomagania Wsi, 2000,Warszawa.

23.Akpinar, N.; Talay, I.; Ceylan, C.; and Gunduz, S. Rural women and agrotourism in the context of sustainaible rural development: A case study from Turkey. Kluwer Jornal. 2004, 6, 473-486.

24.Cawley, M.; Gillmor, D. A.; Leavy, A., and McDonagh, P. Farm diversification:Studies relating to the west of Ireland. 1995, Dublin. Teagasc.

25.Davies, E.T. and Gilbert, D.C. A case study of the development of farm tourism in Wales.Tourism Management.1992, 13(1), 56-63.

26.Lobo, R. E.; Goldman, G.E. Jolly, D.A.; Wallace, B.D.; Schrader, W.L., and Parker, S.A. Agritourism benefits agriculture in San Diego County. 1999, CaliforniaAgriculture, 53(6), 20-24.

27.Sikora, J. Organizacja rucbu turystycznego na wsi, Wydawnictwo WsiP, 1999, Warszawa.

28.Welford, R.; Ytterhus, B. and Eligh,J. Tourism and sustainable development: An analysis of policy and guidelines for managing provision and consumption. Sustainable Development. 1999, 7, 165-177.

29.Goebel, P.; Reuter, C.; Pibernik. R.; and Sichtmann, C. The influence of ethical culture on supplier selection in the context of sustainable sourcing. Int.J. Product. Econom. 2012, 140, 7-17.

30.Državni zavod za statistiku - Hrvatska, popis stanovništva 2011.

31.Zavod za statistiku Crne Gore (MONSTAT). Poljoprivredni popis 2010, Struktura poljoprivrednih gazdinstava, 2011b; Zavod za statistiku Crne Gore, Podgorica, Crna Gora , 2011.

32.LaPan, C., and Barbieri, C.; The role of agritourism in heritage preservation. Current Issues in Tourism, (2014), Vol.17, $\mathrm{N}_{0} .8,666-672$.

33.Jelinčić, D. A. Agroturizam u evropskom kontekstu. Stud .ethnol. Croat. 2007, Vol 19,.269-291.

34.Ruzić,P.; Ruralni turizam Istre, (2011), Institut za poljoprivredu i turizam, Poreč

35.Zavod za statistiku Crne Gore (MONSTAT). Statistički godišnjak Crne Gore, .2015; Zavod za statistiku Crne Gore, Podgorica, Crna Gora , 2016

36.Kušen, E. Terminologija ruralnog razvoja u: Prvi hrvatski kongres ruralnog turizmaPerspektive razvoja ruralnog turizma. Zbornik radova. 2007, p.100.

37.Lane, B.;. "What is rural tourism?” Journal of sustainable tourism, 1994, Vol. 2(7), pp.7-21.

38.Njegovan, Z.; Ekonomika turizma i seoskog turizma, 2016, Poljoprivredni fakultet, Novi Sad, p.1-243

39.Klarić, Z; Gatti, P. (2006). Ekoturizam. U: Hrvatski turizam: Plavo,bijelo,zeleno (ur.Čorak, Sanda i Mikačić, Vesna), 2006, str. 149-166, Zagreb: Institut za turizam

40.Tudisca, S.; Di Trapani, A.M.; Sgroi, F.; Testa, R.and Squtrito, R. Economic analysis of PV systems on buildings in Sicilian farms. Renewable Sustainable Energy Rev. 2013, 28, 691- 701 . 
41.Ballarin, A.; Vechiato, D.; Tempesta, T.; Marangon,F.; and Troiano, S. Biomass energy production in agriculture: A weighed goal programming analysis. Energy policy. 2011, 39, 1123-1131.

42.Dwyer, L.; Forsyth, P., Rao, P.; The price competitiveness of travel and tourism: acomparison of 19 destinations. Tourism Management, 2000, Vol. 21(1), pp. 922.

43.Demirović,D.: Konkurentnost Vojvodine kao destinacije ruralnog turizma, Doktorska disertacija, 2016, Novi Sad, pp 1-327

44.Conaghan, A.; Hanrahan, J; .Global Conformity of Indicators for Eco-Certification Programs. In: Contemporary Issues in Irish and Glbal Tourism and Hospitality (ed.G.Gorman and Z Mottiar), 2010, pp. 93-106. Dublin: DIT

45.Byrd, E.T.; Bosley, H.; E., Dronberger, M.G;. Comparisons of stakeholder perceptions of tourism impact in rural eastern North Carolina. Tourism Management, 2009, Vol. 30(5), pp.693 - 703.

46.Wilson, S.; Fesenmaier, D., Fesenmaier, J., Van Es, J. Factors for success in rural tourism development. Journal of Travel Research, 2001, Vol. 40(2), pp. 132-138.

47.Ahmad, N.A.A., Habibah, A., Hamzah, J., Mohd Y.H.. Understanding the Role of Stakeholder in the Formation of Tourist Friendly Destination Concept. Journal of Management andSustainability, 2012, Vol. 2(2), pp. 69 - 74.

48.Aragón-Sánchez, A.; Sánchez-Marín, G.; Strategic orientation, management characteristics, and performance: A study of Spanish SMEs. Journal of Small Business Management, 2005, Vol. 43(3), pp. 287-308

49.Sheldon, P. J., Abenoja, T. Resident Attitudes in a Mature Destination: The Case of Waikiki. Tourism Management, 2001, Vol. 22(5), pp. 435

50.Štifranić, L.; Debelić, B.; Leader program: Evropskom praksom do vlastitih prilika, 2009, Rijeka.

51.Kaltenborn, B.P.; Andersen, O.; Nellemann, C.; Resident Attitudes Towards Mountain Second-Home Tourism Development in Norway: The Effect of Environmental Attitues. Journal of Sustainable Tourism, 2008, Vol. 16(6), pp. 664-680. 